\title{
Progressive development of circulating polyploid cells in Mytilus with hemic neoplasia
}

\author{
R. A. Elston ${ }^{1}$, A. S. Drum ${ }^{1}$, S. K. Allen, $\mathbf{J r}^{2}$ \\ ${ }^{1}$ Center for Marine Disease Control, Battelle/Marine Sciences Laboratory, 439 West Sequim Bay Road, Sequim, \\ Washington 98382, USA \\ ${ }^{2}$ Shellfish Research Laboratory, New Jersey Agricultural Experiment Station, Rutgers University, Port Norris, \\ New Jersey 08349, USA
}

\begin{abstract}
The progressive development of hemic neoplasia in Mytilus is described using a flow cytometric method. Two experiments were conducted in order to determine the DNA content and evolution of the disease in individual Mytilus. In disease free individuals, either 1 or 2 populations of circulating cell $l_{5}\left(\mathrm{G}_{1 \mathrm{a}}\right.$ and $\left.\mathrm{G}_{1 \mathrm{~b}}\right)$ were detected on the basis of relative DNA content, containing multiples of 2.00 to 2.21 haploid (n) DNA content. In mussels with progressive hemic neoplasia, an increase in an apparently polyploid population (measured $5.1 \mathrm{n}$ ) occurred in conjunction with a decrease in the proportion of $\mathrm{G}_{1 \mathrm{a}}$ cells. Subsequent to the increase of the $5.1 \mathrm{n}$ population, the formation of a second apparently polyploid population of circulating cells with a mean measured DNA content of $10.1 \mathrm{n}$ occurred and increased over time. The presence of these cell populations with these two ploidy levels represented a single population of autonomously replicating polyploid hemocytes in circulation. These polyploid circulating cell populations correspond to morphological changes in circulating cells which are described from hemocytological preparations. In addition, a second, rarer form of the disease, characterized by an increase of tetraploid neoplastic cells in circulation was observed. The 2 forms of the disease may represent alternative chromosomal lesions resulting from 2 alternative modes of integration of a foreign genome into the host genome. The significance of these findings on the observation of progression of the disease and on hypothetical etiologies is discussed.
\end{abstract}

\section{INTRODUCTION}

Proliferative blood cell disorders of bivalve molluscs were first reported by Farley (Farley 1969a, b) in 2 species of Crassostrea oysters and in the blue or bay mussel, Mytilus edulis. Subsequently, morphologically similar disorders have been reported in at least fifteen species of bivalves (Peters 1989) from various locations around the world. The disorders are considered neoplastic in nature and are commonly referred to as hemic neoplasia or disseminated sarcomas, although there is some question as to whether all represent disorders of hemic origin. Where studied in some detail, they are known to be progressive and fatal (Cooper et al. 1982, Elston et al. 1988a). A retroviral etiology has been claimed for hemic neoplasia in the soft shell clam (Oprandy \& Chang 1983, Oprandy et al. 1981), but this claim has not yet been substantiated by repetition or further work on other species. The condition has been demonstrated to be transplantable with whole cells in the cockle (Twomey \& Mulcahy 1988), and with whole cells and cell free homogenate in $M$. edulis (Elston et al. $1988 \mathrm{~b})$. In these conditions, relatively large, undifferentiated cells with a high nucleus to cytoplasm ratio, and frequently observed mitoses (Mix et al. 1979), appear to replace the normal hemocytes in circulation.

The high mitotic index of circulating cells was first observed by Farley (1969a). Later, Lowe \& Moore (1978) used microdensitometry on single samples of preserved individuals' tissues to estimate cellular DNA content of 3.8 to 7.7 times the diploid level for what they considered to be 2 types of abnormal hemocytes. Thus, these reports established that a higher than normal level of mitosis occurred in the condition, and that it resulted in aneuploid levels of DNA.

We present a description of the sequential development of aneuploidy in neoplastic mussels and the apparent cycling of aneuploid populations of cells. This represents the recognition that the typical heterogenous populations of neoplastic cells can represent either 
sequential stages or different forms of the disease. This report is also the first use of cytofluorometric methods to study the ontogeny of bivalve neoplastic blood cells.

\section{MATERIALS AND METHODS}

Mussels from Puget Sound, Washington, USA, known to have a high prevalence of hemic neoplasia, were used for the study. The species designation for mussel populations in the Puget Sound, area is in question. Morphometric analyses indicated they were Mytilus edulis (Elston et al. 1988a); isozyme analysis based on protein electrophoresis indicates they may be Mytilus trossulus (McDonald \& Koehn 1988).

To determine the course of hemic neoplasia infection, 2 experiments were performed in which individual diseased mussels were sequentially sampled. In Expt 1, 36 mussels were placed in a laboratory tank receiving unfiltered flowing seawater. For $76 \mathrm{~d}$, from February 4 , to April 21, 1987, mussels were bled at 3 to 4 wk intervals. In Expt 2, an additional 36 mussels were placed in laboratory tanks and bled at ca 2 wk intervals for 183 d from December 21, 1987 until June 21, 1988. Mussels were bled by inserting a 22 gauge needle into the posterior adductor muscle and withdrawing ca $0.1 \mathrm{ml}$ of blood into a cold buffer diluent $(0.01 \mathrm{M}$ Tris, 6 mM ethylenediaminetetraacetate, adjusted to $\mathrm{pH} 8.4$ and 860 mOsm with $\mathrm{NaCl}$, following Wittke \& Renwrantz 1984). As controls, a neoplasia-free population of mussels from Willapa Bay, Washington, was obtained and sampled on a single occasion to determine baseline DNA content of circulating hemocytes in unaffected individuals.

Each blood sample was prepared for hemocytological and cytofluorometric analysis. For hemocytology, freshly drawn blood, still in diluent, was allowed to settle onto a glass slide, fixed and stained with Feulgen-picromethyl blue (Farley et al, 1969b, Elston et al. 1988a). For flow cytometry, the remaining blood was further diluted in sample buffer and held no longer than $10 \mathrm{~min}$ in a $1.5 \mathrm{ml}$ micro-centrifuge tube. Blood samples were subsequently spun at $300 \times g$ for $2 \mathrm{~min}$ at $4{ }^{\circ} \mathrm{C}$, the supernatant aspirated, and the cells resuspended in a buffer-fluorochrome staining solution. The latter was prepared by adding $10 \%$ dimethylsulfoxide (DMSO) to combined Solutions A (4 parts) and B (1 part), just prior to use. Solution A contained $0.85 \% \mathrm{w} / \mathrm{v}$ $\mathrm{NaCl}, 0.1 \mathrm{M}$ Tris, $1 \mathrm{mM} \mathrm{CaCl}, 0.5 \mathrm{mM} \mathrm{MgCl}_{2}$ and $0.2 \% \mathrm{w} / \mathrm{v}$ bovine serum albumin, adjusted to $\mathrm{pH} 8.0$; Solution B contained $106 \mathrm{mM} \mathrm{MgCl}_{2}, 0.6 \% \mathrm{w} / \mathrm{v}$ Triton $\mathrm{X}-100$ and $50 \mu \mathrm{g} \mathrm{ml} \mathrm{m}^{-1}$ DAPI 4', 6-diamidino-2-phenylindole dihydrochloride). Samples were then frozen and held at $-70^{\circ} \mathrm{C}$ until examination on a Phwye ICP-22 flow cytometer. Since samples for flow cytometric analysis were frozen for each individual mussel on each sampling date, representatives from the different stages of the disease could be selected retrospectively for flow cytometric analysis based on the results of hemocytological evaluation. Immediately prior to flow cytometry, samples were thawed quickly under cold running water and placed on ice. Cell suspensions were syringed 3 times to disaggregate any possible clumps. We examined both fresh and frozen samples and found no clumping due to freezing.

Mussel sperm, obtained from a disease-free population of Mytilus from Humboldt Bay, California, was used as a machine calibration standard. Sperm was obtained by placing a piece of mussel mantle containing mature spermatic follicles into the Tris-EDTA buffer and allowing it to stand on ice for $20 \mathrm{~min}$, following which the mantle tissue was removed, leaving a suspension of active sperm. An equal volume of DAPI buffer solution (see above, 4:1 Solutions A and B) and $10 \%$ DMSO was added before aliquoting and freezing samples at $-70^{\circ} \mathrm{C}$. When needed as standards in flow cytometric analyses, frozen sperm suspensions were thawed and sonicated $3 \times 30 \mathrm{~s}$ at $100 \mathrm{~W}$ with a microtip on a Braun sonicator to disaggregate possible cell clumps. Each experimental sample was analysed twice by flow cytometry, once with and once without sperm standard, eliminating the possibility that aggregates from the standard would affect the results.

The flow cytometer illuminated the cells in the ultraviolet range at $365 \mathrm{~nm}$. The fluorochrome DAPI fluoresces with an intensity proportional to DNA content in the nucleus of the cell. Fluorescence intensity of each cell registered on one of 256 channels. The resulting fluorescence histograms were then analysed with 'M-cycle' (Multicycle, Phoenix Flow Systems, San Diego, CA, USA); a cell cycling software package to assign peak means, amplitudes, coefficients of variation (CV), and relative contribution of each peak to the entire cell population. Where appropriate, the program could estimate the proportion of cells in presumptive $G_{1}, G_{2}$ and $S$ phases of the cell cycle.

Because some cell populations had extraordinarily high ploidy levels that could only be viewed at a wider range setting, corrections were made for non-linearity of each setting. To calibrate between gain settings, samples of mussel blood with high polyploid cell populations were run twice, once with and once without sperm, at each of the two gain settings (total of 4 analyses). Linearity was corrected using a trout redblood-cell standard calibrated to the mussel-sperm standard used in this study. The mussel-sperm standard DNA content measured an average of 0.60 and 0.62 units of the diploid DNA hemocyte content of cells from neoplastic and normal Willapa Bay populations, respectively. Data from normal diploid cells popula- 
Table 1. Mytilus. DNA content and estimated cell cycling parameters of healthy mussel hemocytes as multiples of haploid (1n). Population means, homogeneity and relative distribution of cells. Cell cycling assignments by the M-cycle program are presumptive and based on the distribution of cells by DNA content

\begin{tabular}{lccc|}
\hline Parameter & $\mathrm{G}_{1 \mathrm{c}}$ & $\mathrm{G}_{1 \mathrm{~b}}$ & $\mathrm{~S}$ \\
\hline $\mathrm{n}^{\mathrm{a}}$ & 10 & 3 & $\mathrm{G}_{2}$ \\
Value range & 1.90 to 2.11 & 2.16 to 2.28 & 3.84 to \\
X $\pm \mathrm{SD}$ & $2.00^{\mathrm{b}} \pm 0.06$ & $2.21 \pm 0.06$ & $3.97 \pm 0.08$ \\
Range $(\%)$ under peak & $40.5-98.0$ & $9.0-45.8$ & $0.0-6.3$ \\
a $\mathrm{n}$ : no. of examples measured for each peak; X: mean of each peak, values underlined \\
b All data normalized to diploid value of 2.00n. Variation about the diploid value of 2.00n represents variation in the diploid \\
peak to standard ratio from sample to sample
\end{tabular}

tions was normalized to a ploidy level of 2.00 for purposes of analysis. Thus, the variance about the diploid values (Table 1) represents the variability in the ratio of the diploid $G_{1}$ peak to the sperm standard from one sample to the next. The relationship of higher levels of ploidy to diploid was calculated directly as a ratio of the average values of raw data for those higher ploidy levels to the actual diploid values for each population of cells in a given cytofluorograph

We categorized each mussel as either progressive, chronic/remissive, or without signs of the disease by hemocytology (Elston et al. 1988a) based on the sequential appearance of abnormal blood cells over the experimental period. From this study, only those mussels with clearly progressive disease were evaluated in detail for ploidy levels.

\section{RESULTS}

\section{Normal mussels}

Based on DNA content, 3 populations of circulating hemocytes were observed in uninfected Mytilus from Willapa Bay. These consisted of $2 \mathrm{n}$ cells representing the $G_{1}$ phase of the cell cycle (and designated $G_{1 a}$ ) and a $4 \mathrm{n}$ population representing the $G_{2}$ phase of cells replicating in circulation. In addition a second population of 'hyperdiploid' cells was observed in some individuals at an average measured ploidy level of $2.21 \mathrm{n}$ (designated $G_{1 b}$ ). The condition showing the single $G_{1}$ peak and $G_{2}$ is shown in Fig. $1 \mathrm{~A}$ and the condition in which the diploid, hyperdiploid and $\mathrm{G}_{2}$ phases were seen is shown in Fig. 1B. These latter cases are based on the actual observation of 2 distinct $G_{1}$ peaks. Data for both conditions are given in Table 1. A number of the peaks assigned to $\mathrm{G}_{1}$ a had a high coefficient of variation (i.e. were very broad peaks). Thus, it is possible that some of these peaks in both normal and neoplastic mussels included cells from the $G_{1 b}$ popula- tion. The percentage of cells in $\mathrm{G}_{2}$ was in the 0 to $6.3 \%$ range (mean $2.5 \%$ ), while the proportion of cells in $\mathrm{S}$ phase of the cell cycle was in the 2.4 to $9.5 \%$ range (mean $4.6 \%$ ). Three of 10 mussels examined had both $\mathrm{G}_{1 \mathrm{a}}$ and $\mathrm{G}_{1 \mathrm{~b}}$ cell populations in circulation while the other mussels had only $G_{1 \text { a }}$ populations in addition to the $\mathrm{S}$ and $\mathrm{G}_{2}$ phase cells.

\section{Progressive polyploidy in neoplastic mussels}

Based on the results of hemocytology, the relative proportions of mussels developing the progressive stages of hemic neoplasia were $52 \%$ and $58 \%$ by the end of Expts 1 and 2, respectively (Table 2). These mussels were selected for the following analysis.

Based on flow cytometry, the progressive nature of the disease was evidenced by progressive increases in apparently polyploid cell populations (near incremental measured increases in ploidy) and decreases in the proportion of cells with normal increments of ploidy. Average DNA content in euploid, aneuploid and polyploid cell populations was determined by sequentially examining a number of individuals with progressive stages of the disease (Table 3). Fig. 2 represents a composite view of these cell populations. Five distinct levels of ploidy were observed and one example of a sixth level of ploidy was also documented. DNA content in 3 cell populations corresponded to those values observed in $G_{1 a}, G_{1 b}$, and $G_{2}$ (mean DNA contents $=2.00 n, 2.25 n$, and $4.03 n$, respectively) from uninfected Willapa Bay mussels. During typical progression of hemic neoplasia a fourth and fifth peak appeared sequentially with mean measured DNA contents of $5.08 \mathrm{n}$ and $10.07 \mathrm{n}$ (Fig. 2, Table 3), presumably representing $5 \mathrm{n}$ and $10 \mathrm{n}$ levels of polyploidy. These appeared to form an autonomous cell cycle in which an $S$ phase is represented between the $G_{1}$ $(5.1 \mathrm{n})$ and $\mathrm{G}_{2}(10.1 \mathrm{n})$ of this cell cycle.

The course of the disease is exemplified by following the case of a single individual throughout the sampling 


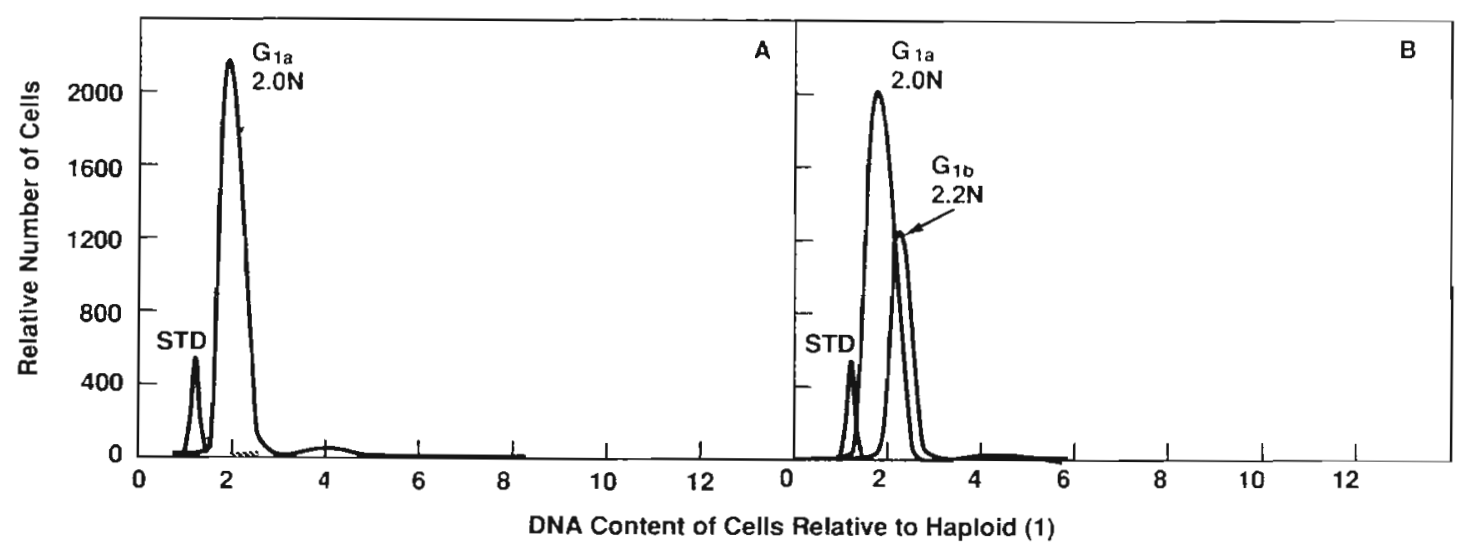

Fig. 1. Mytilus. DNA content of circulating hemocytes from neoplasia-free individuals. Graphs correspond to numerical data given in Table 1. (A) single diploid peak, $G_{1 a}$, with corresponding $S$ and $G_{2}$ phases; $(B)$ diploid $\left(G_{1 a}\right)$ and hyperdiploid $\left(G_{1 b}\right)$ peaks with the hyperdiploid equivalent to $2.21 \times$ diploid. STD: standard

Table 2. Mytilus. Course of hemic neoplasia in mussels as determined by hemocytological examination. Value are proportion (and percentage) of mussels in each category of disease. Placement based on hematological evaluation over course of each experiment (Elston et al. 1988a)

\begin{tabular}{|ccrc}
\hline Expt & Progressive & $\begin{array}{c}\text { Chronic/ } \\
\text { remissive }\end{array}$ & Normal \\
\hline 1 & $19 / 33(58 \%)$ & $9 / 33(27 \%)$ & $5 / 33(15 \%)$ \\
2 & $14 / 27(52 \%)$ & $10 / 27(37 \%)$ & $3 / 27(11 \%)$ \\
\hline
\end{tabular}

period (e.g. Fig. 3, Table 4), At Day 0 hemocytes have a normal DNA profile: only $\mathrm{G}_{1 a}, \mathrm{~S}$, and $\mathrm{G}_{2}$ cells are present, comprising 91,6 and $3 \%$, respectively. By Day 44 a new peak, $5.1 \mathrm{n}$ was observed. During the progressive disease, until the condition was fatal, $G_{1 a}$ cells decreased in frequency while $5.1 \mathrm{n}$ cells became increasingly abundant (Fig. $3 \mathrm{C}$ to E). After 71 d (Table 4) an additional population of cells was observed with a mean DNA content of $10.1 \mathrm{n}$. This population of cells progressively increased in frequency, reaching $10 \%$ of all hemocytes in the sample taken on Day 99 (Fig. $3 \mathrm{E}$ and F). The mussel represented in Fig. 3 died before more samples could be taken. The apparently autonomously cycling population in circulation is shown in Fig. 3F. Over time, this population predominated the hemocytes of this and other affected mussels with an initial replacement of normal hemocytes by the $5.1 \mathrm{n}$ peak followed by an increase in the number of $10.1 \mathrm{n}$ cells. Cells, apparently representing the $\mathrm{S}$ phase of this cell cycle, are seen between the $5.1 \mathrm{n}$ and $10.1 \mathrm{n}$ cells.

In a single individual from each of the 2 experiments, a large increase in the $G_{2}$ population of cells was observed. In one case, in Expt 2, $\mathrm{G}_{2}$ comprised $48 \%$ of the total measured cells in circulation late in the disease process, compared to the average of $3.1 \%$ (range
Table 3. Mytilus. DNA content of hemocyte populations as multiple of haploid among individuals with hemic neoplasia. Mean: mean of 2 experiments. All data normalized to diploid value of $2.00 \mathrm{n}$. Variation about the diploid value of $2.00 \mathrm{n}$ represents variation in the diploid peak to standard ratio from sample to sample. Measured mean values are underlined

\begin{tabular}{|c|c|c|c|}
\hline $\begin{array}{l}\text { Hemocyte } \\
\text { population }\end{array}$ & Expt 1 & Expt 2 & Mean \\
\hline \multicolumn{4}{|l|}{$G_{1 a}$} \\
\hline $\mathrm{n}$ & 11 & 60 & \\
\hline Range & 1.89 to 2.12 & 1.75 to 2.21 & \\
\hline $\mathrm{X} \pm \mathrm{SD}$ & $2.00 \pm 0.06$ & $2.00 \pm 0.12$ & 2.00 \\
\hline \multicolumn{4}{|l|}{$G_{1 b}$} \\
\hline $\mathrm{n}$ & 4 & 2 & \\
\hline Range & 2.26 to 2.36 & 2.22 to 2.28 & \\
\hline $\mathrm{X} \pm \mathrm{SD}$ & $\underline{2.29} \pm 0.01$ & $\underline{2.25} \pm 0.02$ & 2.25 \\
\hline \multicolumn{4}{|l|}{$\mathrm{G}_{2}$} \\
\hline n & 14 & 58 & \\
\hline Range & 3.90 to 4.18 & 3.88 to 4.22 & \\
\hline$X \pm S D$ & $\underline{4.05} \pm 0.08$ & $4.01 \pm 0.10$ & 4.02 \\
\hline \multicolumn{4}{|l|}{$5.1 \mathrm{n}$} \\
\hline $\mathrm{n}$ & 11 & 13 & \\
\hline Range & 4.92 to 5.26 & 4.88 to 5.26 & \\
\hline$X \pm S D$ & $5.05 \pm 0.14$ & 5.10 to 0.14 & 5.08 \\
\hline \multicolumn{4}{|l|}{$10.1 n$} \\
\hline $\mathrm{n}$ & 7 & 5 & \\
\hline Range & 9.60 to 10.46 & 9.86 to 10.46 & \\
\hline$X \pm S D$ & $\underline{9.95} \pm 0.34$ & $\underline{10.18} \pm 0.29$ & 10.07 \\
\hline
\end{tabular}

0 to $8.0 \%$ ) for all mussels with the progressive disease In this mussel an additional small population of cells, estimated at $7.7 \mathrm{n}$ was measured in the last sample before the mussel died. In the second case, the percentage of cells in $\mathrm{G}_{2}$ increased to $12 \%$ of the total population, following which the mussel died. In both cases the blood contained hemocytes judged neoplastic by morphological criteria. 


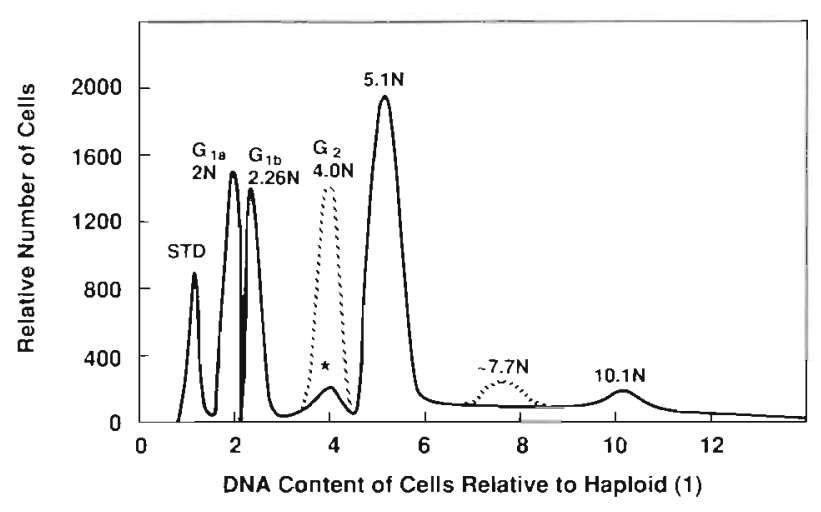

Fig. 2. Mytilus. Composite cytofluorograph showing ploidy relationship of all cell populations observed in this study. Relationship of population $G_{1 b}$ to normal cell cycling or neoplasia is unknown. The 5.1n peak apparently is the $G_{1}$ phase of an autonomously replicating population of cells in circulation for which the $10.1 \mathrm{n}$ peak represents the $G_{2}$ phase. The dashed lines above $G_{2}\left({ }^{\circ}\right)$ indicate the 2 cases in which this population increased in the study, and corresponded to the appearance of morphologically neoplastic cells in circulation. The dashed line at $7.7 \mathrm{n}$ represents the single mussel in which the $G_{2}$ cells appeared to also form a cycling population in circulation, analogous to the 5.1 to $10.1 \mathrm{n}$ population relationship, but relatively rarely observed in this study
It is important to note that the time for progression to irreversible or terminal stages of the disease varied among individuals. Once the proportion of $5.1 \mathrm{n}$ cells had exceeded ca $5 \%$ of all measured circulating cells, the disease was considered irreversible. The time from the normal state to death ranged from 49 to $188 \mathrm{~d}$ among individuals from the 2 experiments. Nonetheless, the typical progressive nature of the disease included a decrease in $\mathrm{G}_{1 \text { a }}$ cells, followed by an increase first in $5.1 \mathrm{n}$ and then $10.1 \mathrm{n}$ cells as represented in the individual in Table 4 and Fig. 3.

The $G_{1 b}$ peak was observed in 4 of 17 neoplastic mussels examined in detail. A suggestion of a minor population of cells of about twice the $G_{1 b}$ ploidy level was observed in some of these mussels. The variability in the $\mathrm{G}_{1 \text { a }}$ to standard ratio (Tables 1 and 3, and Fig. 3) may have masked the expression of $G_{1 b}$ in some cases.

\section{Clinical correlates of polyploidy}

The progressive stages in the disease, as characterized by the DNA content of circulating hemocytes, generally corresponded to progressive morphological

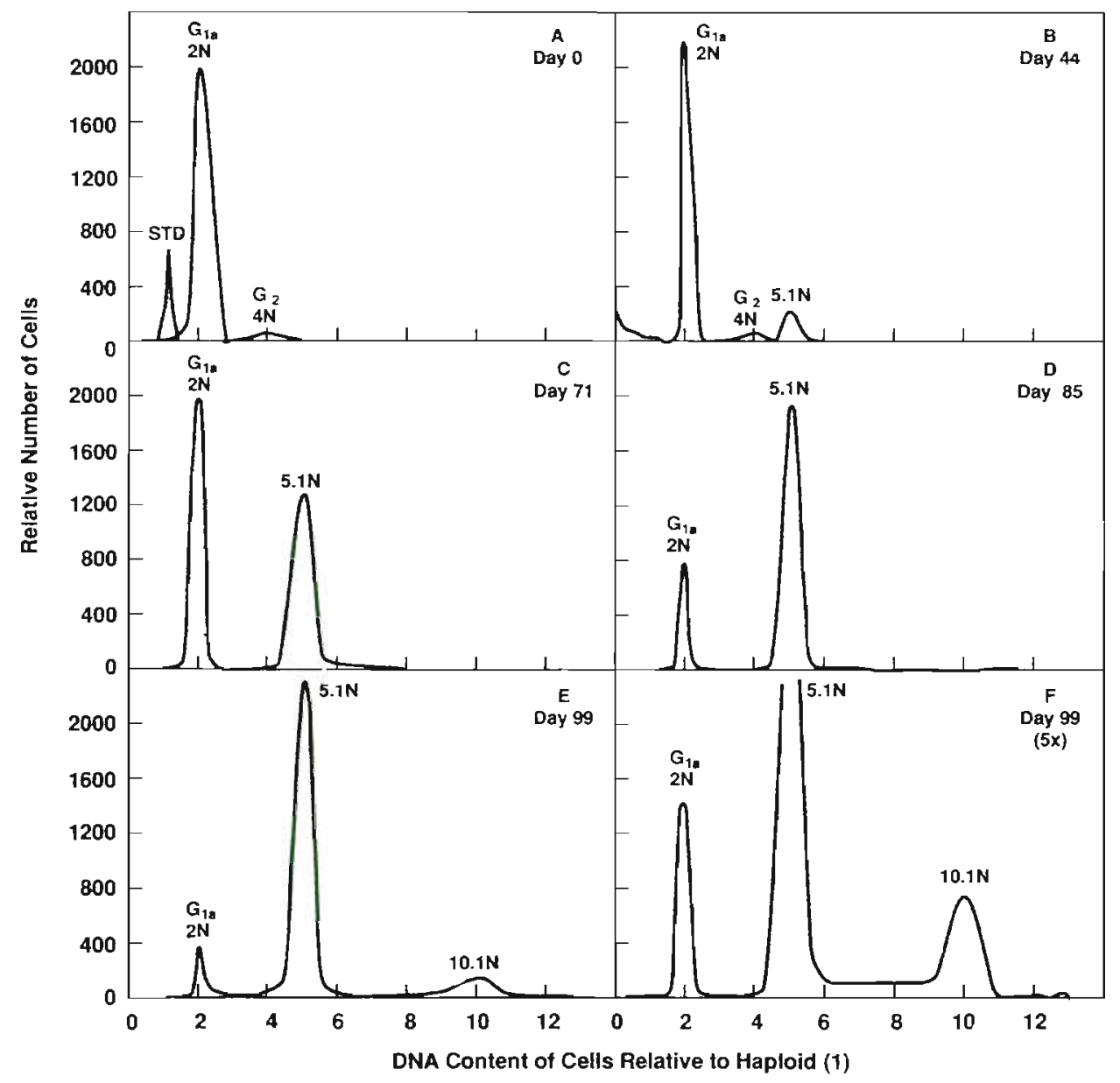

Fig. 3. Mytilus. Sequential development of aneuploid cell populations of an individual with hemic neoplasia (see numerical data in Table 4). (A to E) 5 sequence sample dates. (F) magnification of $E$, showing the apparent cycling of cells from the 5.1 to $10.1 \mathrm{n}$ populations (ordinate scale also $5 \times$ ). Data from same individual as in Table 4 
Table 4. Mytilus. Evaluation of circulating cell popluations in a typical individual with progressive hemic neoplasia. Cell population DNA content means (underlined) and relative proportion of cells in each population

\begin{tabular}{|c|c|c|c|c|c|c|c|c|c|c|}
\hline \multirow[t]{3}{*}{ Sample day } & \multicolumn{3}{|c|}{$\mathrm{G}_{1 \mathrm{a}}$} & \multicolumn{2}{|c|}{$\mathrm{G}_{2}$} & \multicolumn{3}{|c|}{$5.1 \mathrm{n}$} & \multicolumn{2}{|c|}{$10.1 \mathrm{n}$} \\
\hline & \multicolumn{2}{|c|}{$G_{1 d}$} & \multirow{2}{*}{$\begin{array}{l}\mathrm{S} \\
\%\end{array}$} & & & \multicolumn{2}{|c|}{$5.1 \mathrm{n}$} & \multirow{2}{*}{$\begin{array}{l}\mathrm{S} \\
\%\end{array}$} & & \\
\hline & Value & $\%$ & & Value & $\%$ & Value & $\%$ & & Value & $\%$ \\
\hline 0 & 1.91 & 91 & 6 & 3.96 & 3 & & & & & \\
\hline 15 & $\overline{1.78}$ & 94 & 5 & $\overline{3.88}$ & 1 & & & & & \\
\hline 32 & $\overline{1.71}$ & 94 & 5 & 4.02 & 1 & & & & & \\
\hline 44 & $\overline{2.03}$ & 77 & & $\overline{4.15}$ & 2 & 5.13 & 14 & 6 & & \\
\hline 57 & $\overline{2.04}$ & 78 & & $\overline{4.12}$ & 2 & $\overline{5.13}$ & 12 & 4 & & \\
\hline 71 & $\overrightarrow{202}$ & 39 & & & & $\overline{5.26}$ & 46 & 11 & 10.68 & $+a$ \\
\hline 85 & 2.21 & 14 & & & & 5.49 & 71 & 11 & 10.98 & 2 \\
\hline 99 & $\overline{2.2 \overline{1}}$ & 7 & & & & 5.18 & 77 & 6 & $\overline{10.20}$ & 10 \\
\hline
\end{tabular}

changes and behavior of the hemocytes as characterized by the hemocytological method. Fig. 4A represents a normal mussel, characterized by well attached and spread hemocytes with relatively small uniform nuclei. Fig. 4B represents a mussel in a relatively early stage of the disease (same mussel from which Day 44 cytofluorograph, Fig. 3B, was made). Many of these cells are attached normally, but occasional cells with enlarged nuclei, often with bizarre shapes, were observed. Fig. $4 \mathrm{C}$ and $\mathrm{D}$ is also from the same individual sampled at Day 44 , and show some nuclear polymorphism, nuclear enlargement and the tendency of the neoplastic cells to attach to glass by one or several remnant pseudopodia. Fig. $4 \mathrm{E}$ represents cells from a mussel at Day 71 of the progressive disease (Fig. 3C). Hemocytes with clearly enlarged nuclei and prominent nucleoli comprise ca $40 \%$ of the population, although the degree of abnormal morphology does not occur synchronously. Thus, the assignment of such percentages cannot be based on precisely defined criteria. In Fig. 4F, corresponding to the cytofluorograph in Fig. 3D sampled at Day 85, the abnormal cells with enlarged nuclei and nucleoli clearly predominate over the more normal cells and comprise ca $70 \%$ of the population by hemocytological interpretation. At this stage, morphologically normal cells can still be found, although they comprise only about $10 \%$ of the circulating population. Finally, Fig. 4G, corresponding to Fig. 3E from the sequential Day 99 sample, represents the terminal stage of the disease. The neoplastic cells predominate in the population. Cells with very large nuclei and nuclear fragmentation are relatively common. Cells with the relatively uniform large nuclei may correspond to the $10.1 \mathrm{n}$ cells. Cells with nuclear fragmentation and extreme enlargement may correspond to cells with DNA contents outside the predominant populations. DNA contents of nearly $15 n$ were observed in the right-hand tail of the population of $10.1 \mathrm{n}$ cells

\section{DISCUSSION}

This is the first description of the sequential development of bivalve mollusc hemic neoplasia using cytofluorometry. This method has revealed several previously unknown features of the disease. It is now clear that the development of hemic neoplasia is a repeatable sequential process of generation of cells with high ploidy levels. This sequential increase in DNA content of the affected cells also corresponds to morphological changes in the hemocytes although the detailed relationship of ploidy to morphology needs further examination. These results support the contention (Elston et al. 1988a) that the transformed cell population is hemic in origin in Mytilus. However, the origin of hemocytes in normal Mytilus, or bivalves in general, is unknown. Thus, the precise relationship of the neoplastic hemocytes to hypothetical uni- or multi-potential stemcells remains an unknown.

The cell cycle of normal or neoplastic Mytilus hemocytes can be inferred from these results, lacking specific experimental corroboration, such as radiation induced blockage of the completion of $\mathrm{G}_{2}$. Analysis of the cytofluorographs of normal mussels (Fig. 1 and Table 1) suggests that some dividing cells do occur in circulation, accounting for the observed cells in $S$ phase and $G_{2}$. Apparently, the hyperdiploid population ( $G_{1 b}$ ) represents a distinct normal cell population but its significance to either normal or neoplastic mussels could not be definitively determined from this study. It is possible that the populations of cells represented by peak $G_{1 b}$ may be more common than is readily apparent, their presence masked by the typically predominant $G_{1 a}$ peak. This interpretation is supported by the higher than expected variation in the $G_{1 \alpha}$ to standard ratios encountered in this study which can be observed in Fig. 3 representing a single mussel. In fact, there may be several populations of normal hemocytes in circulation which yield slightly 

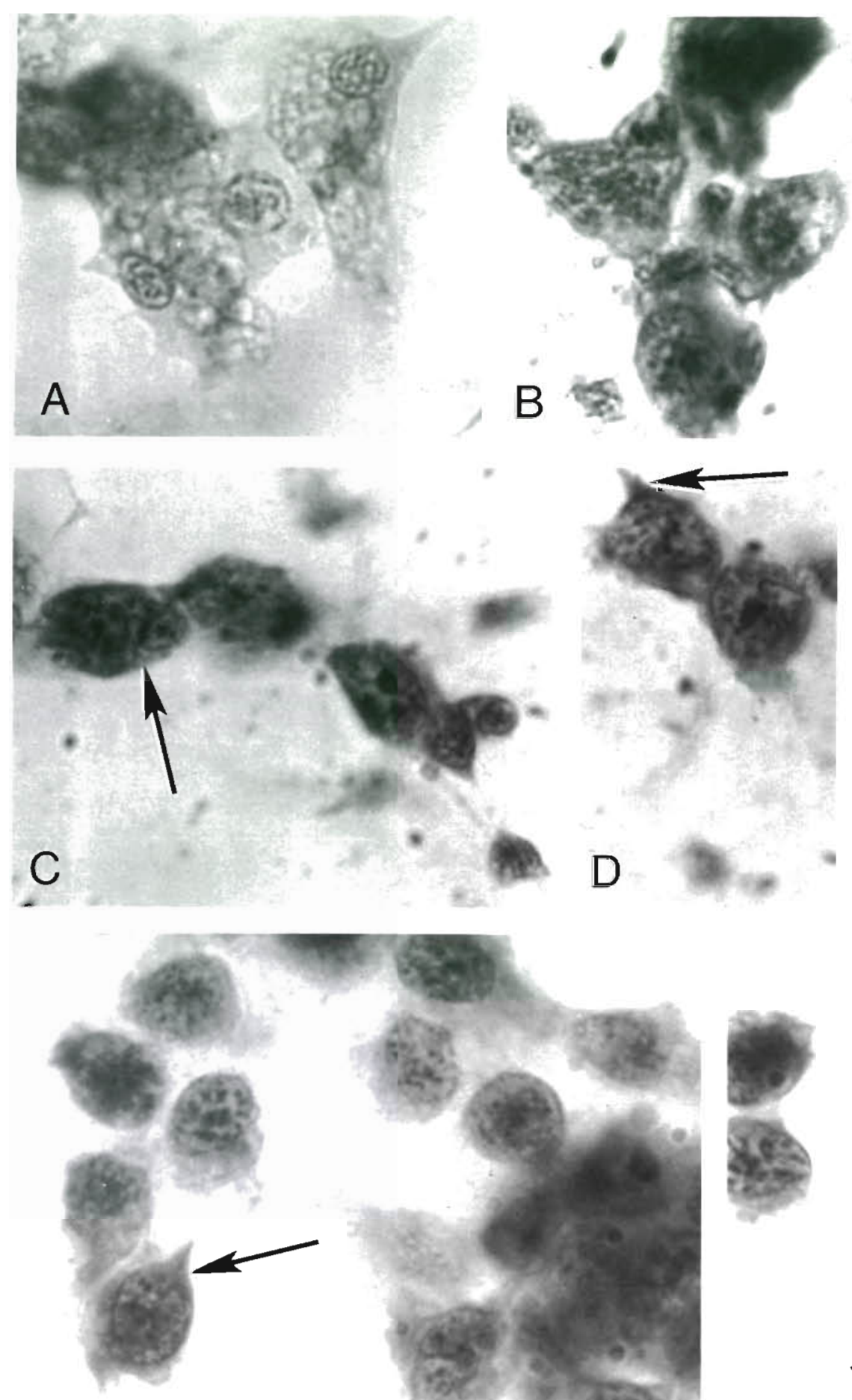

$\mathrm{F}$
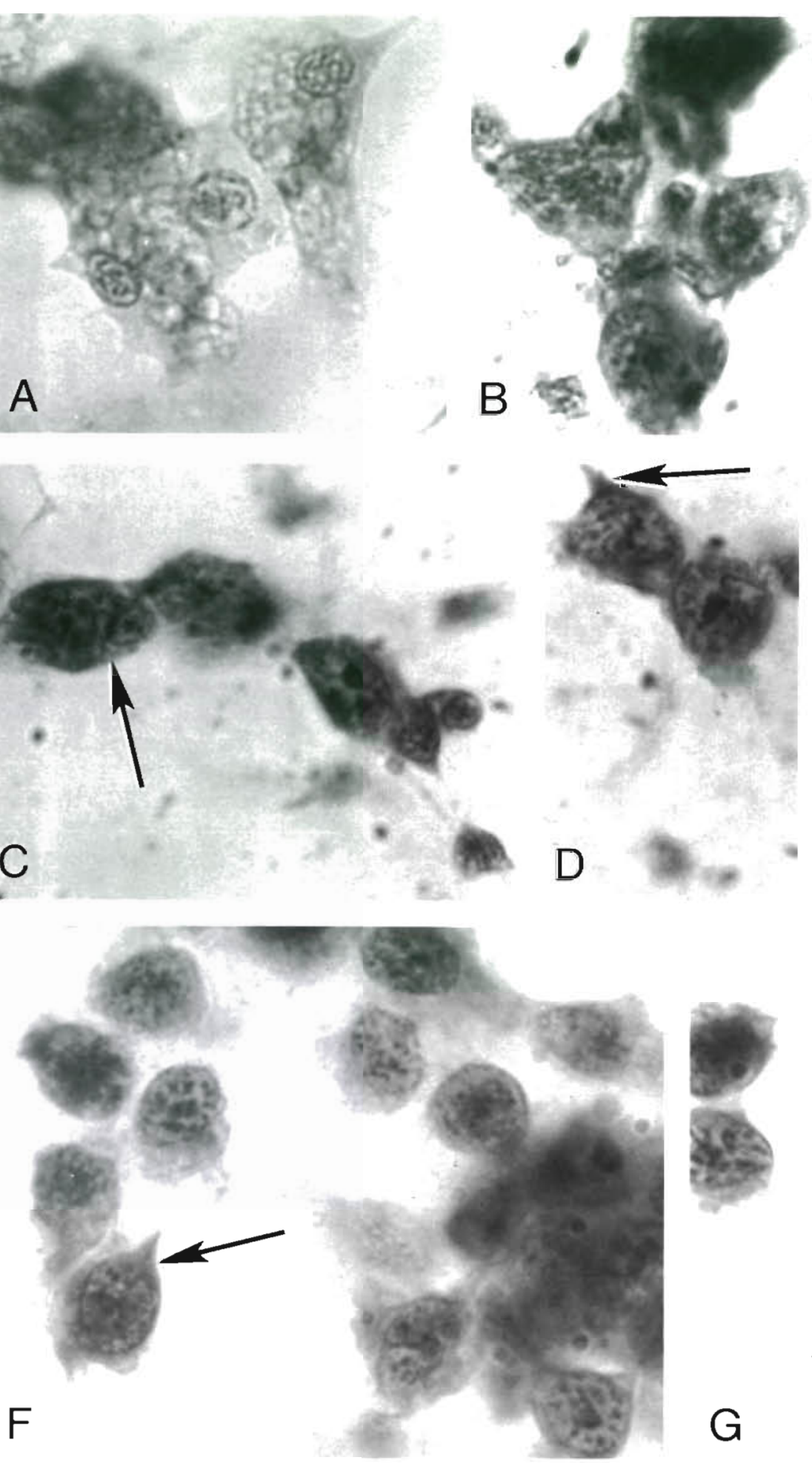

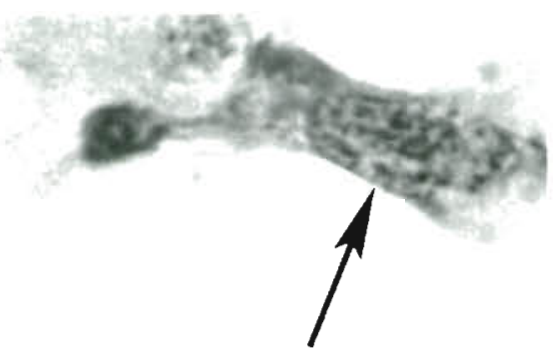

E

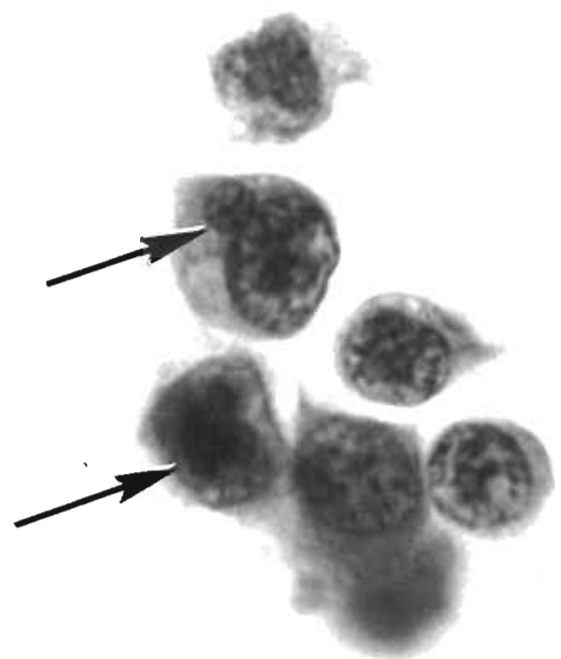

Fig. 4. Mytilus. Hemocytological preparations. (A) Neoplasia-free individual. The hemocytes, predominantly granulocytes, are attached and broadly spread out on the glass slide. The nuclei are rounded, relatively small and of uniform size. (B) Mussel at relatively early stage of hemic neoplasia (same individual from which flow cytofluorograph in Fig. 3B was made, Day 44). Arrow indicates a neoplastic cell with enlarged nucleus and prominent nucleolus, but which is broadly spread out on the glass substrate. $(C$ and D) Hemocytes from same mussel as in B (Day 44) showing neoplastic cells with enlarged nuclei. Arrow in $C$ indicates an irregular or fragmented nucleus, and arrow in D shows the typical remnant pseudopodia by which neoplastic cells tenuously adhere to the substrate. (E) Mussel at Day 71 of progressive disease (Fig. 3C) showing common enlarged nuclei and prominent nucleolus. (F) Mussel at more advanced stage of hemic neoplasia (Day 85, Fig. 3D). Most cells are less well attached than in previous samples and adhere to the glass slide by the remnant pseudopodia, all unidirectionally oriented from the cell (arrow). (G) Advanced, near terminal stage of the disease (Day 99, Fig. 3E). All affected cells have only minimal attachment to glass by the unidirectional remnant pseudopodia. Fragmented nuclei and those with highly irregular shapes are relatively common at this stage of the disease (arrows) 
different apparent DNA content levels using the methods applied in this paper It is possible that an amplification of $G_{1 b}$ cells indicates initiation of the neoplastic process but more detailed study of the initiation of the disease is needed to determine the role, if any, of relatively minor shifts in the ploidy level of diploid populations of cells. It is also interesting to note that $\mathrm{G}_{1 \mathrm{~b}}$ cells apparently replicate in circulation in some cases.

A retroviral etiology has been postulated in a similar condition in Mya arenaria (Oprandy et al. 1981, Oprandy \& Chang 1983). The progression of this disease may be initiated when hematopoietic stem-cells are infected with the hypothetical virus. Thus, transformation of these cells would take place at the yet unknown site of hematopoiesis with the subsequent deregulation of cell division evidenced by the increased proportion of dividing cells in circulation, as is observed in this disease. The disappearance of $\mathrm{G}_{1 \mathrm{a}}$ cells might then result from the virtual replacement of normal hematopoiesis by the transformed neoplastic cells. A chromosomal lesion may lead to the unregulated replication of $G_{1 a}$ cells, such that they divide to form a polyploid population with a relative DNA content of $5.1 \mathrm{n}$. The observations further suggest the unusual initiation of another division such that the $5.1 \mathrm{n}$ peak represents the $G_{1}$ phase of an anomalous cycle and the $10.1 \mathrm{n}$ peak represents the $G_{2}$ phase of the cycle. However, the observations made in this study do not permit an estimation of the cycling rate of any of the observed cell populations. Nonetheless, the observation of an apparently autonomous population of cycling neoplastic cells in circulation is remarkable. The 2 observations of the development of a large proportion of $\mathrm{G}_{2}$ cells with neoplastic morphology indicate that a second form of the disease exists. This could result from an alternate site for the insertion of a retroviral genome into the host genome resulting in the deregulation of normal cell division and differentiation without the alteration in normal levels of ploidy seen in the more typical 5.1 to $10.1 \mathrm{n}$ progressive disease. Conceivably, 2 forms of the disease could result from alternative infection of cells represented by either the $G_{1 a}$ or the $G_{1 b}$ populations. The integration of retroviral genes into the host genome is an established basis of neoplastic transformation in humans and other vertebrate animals (Varmus 1988). The integration process may depend on the presence of suitable sites, thus accounting for consistent patterns of resultant chromosomal lesions and polyploidy, like that observed in Mytilus hemic neoplasia. Conceivably, other sites may occasionally incorporate viral genes, possibly accounting for the occasional but less frequent transformation of other stem cell lines or a different clinical behavior than that typically observed in the susceptible stem cell line.

The results of this report can be compared with the earlier findings of Lowe \& Moore (1978) using microdensitometry to estimate DNA content of Mytilus edulis with the same or similar condition from southern Britain. In that study, the authors characterized 16 fixed specimens from a population of ca 3000 and measured 20 cells of each type from each mussel. These authors reported 2 morphologically abnormal types of cells with differing DNA contents. They noted that both abnormal cell types were similar in appearance to the normal 'lymphocytes' described by Moore \& Lowe (1977). Their Type A abnormal cells had nuclei in the 8 to 9 m diam. range, examples of multiple nucleoli and estimated DNA contents of 3.8 to $4.3 \times$ diploid $(7.6$ to $8.6 \mathrm{n}$ ). Their Type $\mathrm{B}$ abnormal cells had nuclei in the 9 to $10 \mu \mathrm{m}$ diam. range, single nucleoli and estimated DNA contents of 6.8 to $7.7 \times$ diploid ( 13.6 to $15.4 \mathrm{n}$ ). It is not possible to be certain that Lowe \& Moore (1978) were working with the same disorder of Mytilus although the morphological description and the estimated ploidy levels are similar. The cytofluorometric method measures total DNA content from many more individual cells from the circulating population than does microdensitometry and thus yields a more faithful representation of the population. In the present study, some cells with DNA contents as high as about $15 \mathrm{n}$ were observed in the right-hand tail of the $10.1 \mathrm{n}$ population, corresponding with the Lowe \& Moore (1978) estimate of maximum levels of DNA content.

In the original description of this disease (Farley 1969a), the presence of a relatively high proportion of dividing cells which appeared to contain excessive numbers of chromosomes was noted. Although it was not possible to make accurate counts of chromosomes from histological material Farley (1969a) estimated that at least twice as many chromosomes occurred in the neoplastic cells in comparison to normal cells. In addition, he noted tripolar and tetrapolar figures and displaced groups of chromosomes. Thus, Farley (1969a) made observations of the chromosomal aberrations which are the basis for the uniformly anomalous pattern of polyploid cell development described in this paper.

The association of chromosomal defects with human cancers has been recognized for some time (Yunis 1983). In tact, consistent chromosomal defects are known to be present in most human neoplasia. The most common types of chromosomal anomalies are band deletions or reciprocal translocations between two chromosomes. Solid tumors tend to be associated with band deletions while leukemias, lymphomas and some carcinomas show a reciprocal translocation. Trisomy (triplicate chromosomes), though less common than reciprocal translocations in leukemias and lymphomas, has also been observed in some patients with chronic lymphocytic leukemia and acute non-lymphocytic leukemia. These primary chromosomal 
defects affect stem cells in human neoplasia. Further detailed study of the chromosomal aberrations could help reveal the site and mechanism of underlying molecular events in the development of hemic neoplasia of bivalve molluscs.

The advancement of knowledge of hemic neoplasia in Mytilus is important to understand basic processes in marine invertebrates. In addition, it is likely that Mytilus hemic neoplasia may serve as a model to elucidate important facets of certain human cancers. In order to advance both of these objectives, specific chromosomal lesions leading to the observed sequence of aneuploidy need to be determined. In addition, the underlying molecular lesions, whether induced by a virus or other cause, which lead to these chromosomal lesions need to be identified.

Acknowledgements. This work was supported by the National Cancer Institute and the US Army Medical Research and Development Command under Grant No. SRC (*), 5 RO1 CA 44269-02.

\section{LITERATURE CITED}

Cooper, K. R., Brown, R. S., Chang, P. W. (1982). The course and mortality of a hematopoietic neoplasm in the soft-shell clam, Mya arenaria. J. Invertebr. Path. 39: 149-157

Elston, R. A., Kent, M. L., Drum, A. S. (1988a). Progression, lethality and remission of hemic neoplasia in the bay mussel, Mytilus edulis. Dis. aquat. Org. 4: 135-142

Elston, R. A., Kent, M. L., Drum, A. S. (1988b). Transmission of hemic neoplasia in the bay mussel. Mytilus edulis, using whole cells and cell homogenate. Devl. comp. Immun., N.Y 12: 719-727

Farley, C. A. (1969a). Sarcomatoid proliferative disease in a wild population of blue mussels (Mytilus edulis). J. nat Cancer Inst. 43 (2): 509-516

Farley, C. A. (1969b). Probable neoplastic disease of the

Responsible Subject Editor: Dr A.K. Sparks, Seattle, Washington, USA hematopoietic system in oysters, Crassostrea virginica and Crassostrea gigas. National Cancer Institute Monograph 31, US Government Printing Office, Washington, D.C., p. $541-555$

Lowe, D. M., Moore. M. N. (1978). Cytology and quantitative cytochemistry of a proliferative atypical hemocyte condtion in Mytilus edulis (Bivalvia, Mollusca). J. nat. Cancer Inst. 60: 1455-1459

McDonald, J. H., Koehn, R. K. (1988). The mussels Mytilus galloprovincialis and $M$. trossulus on the Pacific coast of North America. Mar Biol. 99: 111-118

Mix, M. C., Hawkes, J. W., Sparks, A. K. (1979). Observations on the ultrastructure of large cells associated with putative neoplastic disorders of mussels, Mytilus edulis, from Yaquina Bay, Oregon, J. Invertebr. Path. 34: 41-56

Moore, M. N., Lowe, D. M. (1977). The cytology and cytochemistry of the hemocytes of Mytilus edulis and their responses to experimentally injected carbon particles. J. Invertebr Path. 29: 18-30

Oprandy, J. J., Chang, P. W. (1983). 5-bromodeoxyuridine induction of hematopoietic neoplasia and retrovirus activation in the soft-shell clam, Mya arenaria. J. Invertebr. Path. 42: 196-206

Oprandy, J. J., Chang, P. W., Pronovost, A. D., Cooper, K. R. Brown, R. S., Yates, V. J. (1981). Isolation of a viral agent causing hematopoietic neoplasia in the soft-shell clam, Mya arenaria. J. Invertebr. Path. 38: 45-51

Peters, E. C. (1989). Recent investigations on the disseminated sarcomas of marine bivalve molluscs. In: Fisher, W. F. (ed.) Disease processes in marine bivalve molluscs. American Fisheries Society, Bethesda, Maryland, Special Publication 18, p. 74-92

Twomey, E. Mulcahy, M. F. (1988). Transmission of a sarcoma in the cockle Cerastoderma edule (Bivalvia; Mollusca) using cell transplants. Devl. comp. Immun., N. Y. 12: $195-200$

Varmus, H. (1988). Retroviruses. Science, N. Y. 240: $1427-1435$

Wittke, M., Renwrantz, L. (1984). Quantification of cytotoxic hemocytes of Mytilus edulis using a cytotoxicity assay in agar. J. Invertebr Path. 43: 248-253

Yunis, J. J. (1983). The chromosomal basis of human neoplasia. Science, N. Y 221:227-236

Manuscript first received: July 18, 1989

Revised version accepted: November 1, 1989 